\title{
Why save a minority language? Meänkieli and rationales of language revitalization
}

\author{
JUHA RIDANPÄÄ
}

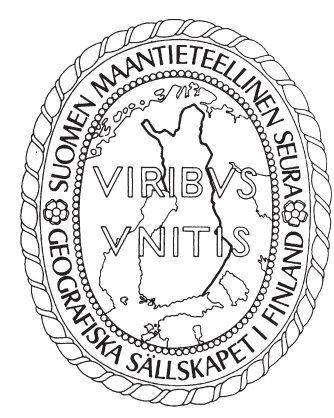

Ridanpää, J. (2018) Why save a minority language? Meänkieli and rationales of language revitalization. Fennia 196(2) 187-203. https://doi.org/10.11143/ $\underline{\text { fennia.74047 }}$

$\boldsymbol{\nabla}$ This article examines the rationales for language revitalization and their materialization on a local scale. The starting premise is that, due to specific social, cultural, as well as spatial circumstances, there exists a wide variety of rationalizations for why saving endangered languages is important. The complexity of the matter is discussed with regard to Meänkieli, a minority language spoken in northern Sweden, which has a long and unique history of marginalization. The article bases on group discussions conducted with Meänkieli speaking cultural activists in northern Sweden during the fall of 2015 and the spring of 2016. The present examination of the group discussions reveals how the rationales of saving the language are inherently interrelated with questions concerning identity formation, educational principles and the sovereignty of minority groups. The analysis also reveals how, due to the complex nature of local history, there is no consensus on whether the recent progress in language revitalization is unanimously a positive change or not.

Keywords: language revitalization, minority languages, marginalization, narrative, group discussions, identity

Juha Ridanpää, Geography Research Unit, University of Oulu, P.O. BOX 8000, FI-90014 University of Oulu, Finland. E-mail: juha.ridanpaa@oulu.fi

\section{Introduction}

According to various estimates there are over 3,000 languages in the world that are in danger of disappearance, but instead of protecting them, we are, as Skutnabb-Kangas $(2002,2)$ formulates it, "killing them as never before". Among the language researchers, from the late 1960s to 1990s, the views towards the possibilities of revitalizing endangered languages have changed from negative to more positive (Spolsky 1995). Minority languages have been the subject of a vast amount of studies across disciplinary boundaries, and what connects them today is a shared opinion that the work for revitalizing vanishing minority languages is extremely important per se. In current studies, it is often taken for granted that there is a shared urge to save endangered languages from disappearing, yet, in the background, there is a range of different rationales for why saving the languages is important in the first place. These partly interconnected lines of argument pertaining to the relevance of language work stem from different ideological viewpoints, namely, the ideals of cultural activism and educational and socially critical argumentation.

This article starts with a theoretical discussion on how the need for language revitalization is rationalized across the disciplinary boundaries. The premise of this study is that, in a specific local setting, the basic rationales of language revitalizing become materialized in much more complicated 
manner, due to specific social, cultural, as well as spatial circumstances and histories. By using Meänkieli - a minority language spoken in northern Sweden - as an example case, the article discusses how different rationales of language revitalization are not only overlapping and interconnected, but geographically and socio-politically conditioned as well. The analysis is based on group discussions conducted with local culture workers. Through a narrative inquiry of the conducted discussions it is also illustrated how, within a single minority group, there exist various different, even conflicting rationalizations for language work. The article also discusses the potential reverse of language revitalization activity.

\section{Rationalizing language revitalization}

When examining language revitalization efforts, any number of social, economic, and political dynamics must be taken into account, as they determine what is possible. As with any social or political movement, language revitalization efforts are inherently contextualized by the communities in which they occur. These contexts include everything from the day-to-day lived experiences of community members to overarching governmental systems and policies at all levels. (Davis 2016, 101)

Like many other scholars, Hinton (2001) starts her analysis of endangered languages with a fundamental question: why being worried about languages diminishing matters? According to Hinton $(2001,5)$, "the world stands to lose an important part of the sum of human knowledge whenever a language stops being used". Respectively, Grenoble and Whaley $(2006,19-20)$ introduce three reasons for why languages should be considered worth revitalizing. Firstly, languages in themselves are to be considered cultural treasures. Secondly, language diversity fosters cultural diversity, and thirdly, revitalizing minority languages both expands and protects minority rights more broadly.

For many scholars across disciplinary boundaries, the second argument from the study by Grenoble and Whaley (2006) - the importance of cultural diversity - represents a pillar of language revitalizing work. In many studies it is either explicitly or implicitly stated how linguistic diversity, as a part of cultural heterogeneity, is valuable in itself (e.g. King 2008). Skutnabb-Kangas $(2002,2)$, for instance, argues that "cultural diversity is as necessary for humankind as biodiversity is for nature". This is a perspective, or a statement, in which the disappearance of languages is explained within the context of the process of globalization. In the early 1990s, it was argued that globalization has brought along a so called 'reversing language shift' (Fishman 1991). This premise is present for instance in studies in which global communication corporations, such as Microsoft and Facebook, are perceived as a threat to language revitalization (Romero 2016). Although globalization has done more harm than good to minority languages, some studies have focused on how modern information technologies could be used, or developed, for the benefit of minority language education (e.g. Warschauer et al. 1997; Hermes \& King 2013).

Language is inherently connected with knowledge and thus, when languages diminish, part of human knowledge is lost with it. The threat of globalization is in connection to a widely employed juxtaposition in which endangered languages are associated with conservatism as they are assumed to be spoken by a soon-passing generation, while younger generations stand for the ideal and values of modernism, liberalism and globalization (e.g. Dorian 1994). Hence, activating the youth to get interested in linguistic roots is a major challenge for language revitalization work. There is a vast amount of studies that approach the issue of language revitalization from the viewpoint of its educational benefits. In many of these studies, education is perceived as a tool or a solution for language revitalization, but there are also studies in which language revitalizing is perceived as a means for wider educational purposes (e.g. Hinton 2011; Sumida Huaman 2014). In many cases, minority language education is conceived as a tool with which the history of otherness, which is, unfortunately, shared by most minority languages, can be renegotiated (see Hornberger 2006).

It is regrettable, but relatively common that minority languages are, especially among youth, considered a skill to be ashamed of (McCarty et al. 2009, 300-302). As is widely recognized, this is also one of the key reasons for why several minority languages are vanishing. One major force that can alter and change young people's attitudes and values towards their language and identity is the 
school system. An illustrative example of how minority language education can be mobilized can be seen in the work of the Maori language nests in Aotearoa, New Zealand and the creation of a nationwide Maori language education system (Rata 2007). At the time when the Maori language had become seriously endangered, members of the community founded daycare places for children under school age (King, J. 2001); in these 'kohanga reo' ('language nests'), older Maori speakers transmitted the language to the children and, to some extent, to their parents as well. Today, several minority groups use similar systems of 'language nests' for the benefit of keeping their endangered languages alive through education (Ridanpää \& Pasanen 2009; Olthuis et al. 2013; Pasanen 2015). Behind all this work in New Zealand, there were a small number of people with an ideological commitment to speaking their native language and continuing the Maori cultural heritage (Fishman 1991 , 230-250). It is thus often emphasized how language revitalization is a fundamentally communal activity, or as Rice $(2009,37)$ puts it, "it takes a community of people to revitalize an Indigenous language". In a similar way, Grenoble and Whaley (2006) emphasize how revitalizing is first and foremost community-driven activity.

Linguistic diversity can be considered as a vital part of human condition, but special emphasis has been paid on how language is an essential part of people's identity. Language work is an integral part of how the identity of feeling and especially 'being indigenous' is put into practice (cf. King, K. 2001). With regard to this, Friedman $(2011,633)$ has argued that

[a] primary task of language revitalization movements is therefore to revalue a subordinate language and grant it prestige through promotion of ideologies such as those representing the language as an emblem of ethnic or cultural identity or establishing it as a medium for valued functions such religious practices, literacy, or 'high culture'.

Thus, along with its instrumental and communicative roles, one of the primary functions of language is to maintain a group identity, and consequently, language has a key role in the process of construction of human identities (Edwards 2010). It is particularly in the case of ethnic minorities that language is often perceived as being the same as identity; "we are our language", as the title of Meek's (2010) major work formulates it. Other article title from Woolard (2003), "we don't speak Catalan because we are marginalized", crystallizes how ethnic identities are often embedded together with minority languages. In these critical insights, it is underscored how (minority) people are raised into and in their language, into their mother tongue. Native American youth, for instance, have in the interviews called the minority language they speak 'blood language', thus conveying the integral part of language in the formation of human identity (McCarty et al. 2009, 300; see also Albury 2017). Correspondingly, for emigrant minority groups, language functions as a performative tool with which identity and sense of belonging can be sustained (Sullivan 2012).

According to Costa and Gasquet-Cyrus $(2013,213)$ "languages are social and historical products, the definition of which constitutes an ideological battle in which other social issues are embedded". Being linguistically marginalized is essentially in connection to how linguistic minorities are being socially othered in a wider context. In this respect, linguistic revitalization is ultimately a matter of sovereignty and self-determination. Sovereignty is an elemental part of basic human rights, both in cases of individuals and groups. The topic of language loss is usually associated with and studied within the context of indigenous groups. By the same token, the focus is directed at the wider issues of social marginality and the heritage of colonialism (McCarty et al. 2015; Ridanpää 2016). According to Hinton $(2001,5)$ "the loss of language is part of the oppression and disenfranchisement of indigenous peoples, who are losing their land and traditional livelihood involuntarily as the forces of national or world economy and politics impinge upon them". The reverse side of this critical and justified approach is that, in minority language research, the study is commonly conducted within the theoretical context of nativeness, thus paying less attention to so called 'new speakers' (O'Rourke \& Pujolar 2013).

The problematics of language revitalization are also related to the problematics of nationalism. The condition of being linguistically marginalized effectively means a reduced sense of belonging to the state (Valentine \& Skelton 2007). Minority languages are ingredients in wider societal discussions about the confrontations between the ideology of nationalism and liberal democracy (May 2012). Language emancipation often requires linguistic standardization, which, instead of the needs of 
minority language speakers, often serve, the political interests of nation-states (Lane 2011). On the other hand, a more predominant opinion is that language revitalization, first and foremost, can be utilized as a means by which it is possible to tear away from past ideologies of colonialism (Wilson 2004; Hermes 2012). For national minorities, language revitalization often works as a tool for rediscovering an othered identity and a sense of pride (Napurí 2016; Ridanpää 2017). In this way, the endeavors to 'save the language' may gain a major symbolic value (Sallabank 2013). In fact, scholars across the disciplinary boundaries have been criticized for approaching minority languages with an assumption of impending doom, whereas a more fertile perspective to the topic would be to focus on community building and collaboration (Hermes 2012).

When scrutinizing the connections between shared identity and the social status of a minority language, various aspects studied within the field of human geography are often present. In fact, this 'geographical eye' has a more general role in terms of how minority languages are approached. 'Where is the language spoken?' is often one of the elementary starting points when introducing a specific endangered language. For example, in Harrison's $(2008,2)$ work When Languages Die and Tsunoda's (2005, xxiv) comprehensive introduction to the topic, Language Endangerment and Language Revitalization, there are illustrations in which the 'approximate' locations of studied endangered languages are shown on a map of the world. Attaching (linguistic) minorities to certain regions is one of the basic means by which regional stereotypes are constructed. This can be seen, for instance, in how northern regions are associated with marginality, the stereotypes connected to indigenous groups and their 'extraordinary' cultural characteristics, such as endangered language, has been in key role over several centuries (Ridanpää \& Pasanen 2009; Ridanpää 2016). In this way, the perception of a minority language can turn a region into a marginal one. Correspondingly, in studies of Aboriginal minorities, it has been emphasized how identity and language are inherently interconnected to ownership of land (Gibson 1998; Baloy 2011). As important as these issues are, it could also be asked whether this ever increasing desire to revitalize endangered languages is connected to a form of contemporary exoticism towards endangered ethnic minorities.

\section{The socio-historical background of Meänkieli}

The creation of modern nation states and their borders has played a key role in the process through which Meänkieli, a language spoken in northern Sweden, has turned into and been acknowledged as a minority language (Pietikäinen et al. 2010). The history of Meänkieli as a minority language emerges at the beginning of the $19^{\text {th }}$ century when, in the aftermath of the war of 1808-1809, the territory of Finland was separated from Sweden and annexed to Russia as the autonomous Grand Duchy of Finland. As a result, the new border, a line drawn along the Torne River, divided the historically, linguistically, economically and culturally more or less homogeneous region of the Torne Valley between two states. Consequently, the Finnish-speaking population on the Swedish side of the Torne Valley region became a linguistic minority, whereas the people living in the territory annexed to Russia began to identify with the majority population and assumed the status of the national majority when Finland gained independence in 1917. When Finland was striving for independence, raising the selfconfidence of the Finnish speaking population through education and major changes in legislation such as the language manifesto of 1863 - played a crucial role (Peltonen 2000).

From the late $19^{\text {th }}$ century until the middle of the $20^{\text {th }}$ century, the Finnish-speaking regional minority on the Swedish side of the Torne Valley was under pressure towards linguistic and cultural integration (e.g. Huss 1999; Elenius 2002). The condition of being a linguistic minority began to develop into an issue of social 'othering' in the late $19^{\text {th }}$ century when the Swedish national 'försvenskningspolitik' entailed the exercising of powerful political pressure on marginal groups in order to integrate them linguistically and culturally into the modern nation-state. Through institutional control, particularly the school system, the marginalization of the Swedish Torne Valley became a concrete, everyday feature of people's lives in the area. For instance, during the first half of the $20^{\text {th }}$ century, speaking Finnish at school was forbidden (Júlíusdóttir 2007, 41). For centuries, bilingualism was conceived as 'halflingualism', the unsatisfactory proficiency in both languages and something to be ashamed of (Hansegård 1990; Ahola 2006, 28). 
In the 1970s, the region's consciousness of being socially marginalized rose remarkably along with the ethnic renaissance, the rise in social self-esteem and aspirations to preserve one's own culture and language during the late $20^{\text {th }}$ century (Lindgren 2000; Winsa 2007). The organization for revitalizing Tornedalian culture and language, Svenska Tornedalingars Riksförbund (STR-T), was established in 1981. In addition, several individual activists, as the politician Ragnar Lassinantti (1915-1985) and culture activist/novelist Bengt Pohjanen have worked in different roles towards language revitalizing. As a symbolic marker for ethnic belonging, the language spoken in the region was not called Finnish anymore, but 'Meänkieli', literally 'our language'. In Finland, Meänkieli is usually defined as a dialect of Finnish, while in Sweden, as a result of identity work, the language has gained officially recognized status as an independent minority language. In 1984 Pohjanen published Kasaland, the first novel in which Meänkieli was used and in 1996 a grammar of Meänkieli, Meänkielen Kramatiikki, thus providing the basis for Meänkieli as a literary language (Prokkola \& Ridanpää 2011). Regional self-esteem and social rights of Meänkieli speaking minority of Sweden have been recurring themes in Pohjanen's cultural production (Karlsson 2004).

Similarly, for instance, to the regional language of Latgalian in Eastern Latvia (Marten 2012), the status of being a stand-alone language - as is the case with Meänkieli - has been a source for controversy over several decades. Although the distinct status of Meänkieli has often been questioned (Piasecki 2014, 13), in 2000, the language was granted official status as a minority language in five municipalities in northern Sweden: Gällivare, Kiruna, Haparanda, Pajala and Övertorneå. Currently, Meänkieli, a dialectal expression meaning 'our language', is defined as a severely endangered language (Laakso \& Sarhimaa 2016) which has, according to Ethnologue: Languages of the World, approximately 30,000 speakers. Although the work conducted by language activists has aroused general interest in Meänkieli, the number of speakers is decreasing due to continuous immigration to southern Sweden. The exact number of Meänkieli speakers is very difficult to estimate since people living in the Torne Valley are often uncertain whether the language they use can actually be defined as Meänkieli. As the origin of the language lies in Finnish, Meänkieli is often seen, particularly in Finland, as a dialect of Finnish instead of a separate language of its own. Characteristic of Meänkieli is lexical borrowing from Swedish, certain forms of regression when compared to the development of the variant of Finnish spoken in Finland during the past 200 years and extensive and regionally variable use of $h$ consonants in final syllables (Vaattovaara 2009).

According to the ELDIA (European Language Diversity for All) media analysis project funded by European Commission and conducted between 2010 and 2012, the picture of Meänkieli speakers is bipolar. On one hand, there is a perception of the group of Meänkieli speakers as passive - as an oppressed and harshly treated by the majority population. On the other hand, there is a picture of Meänkieli speakers as a group which is, in spite of oppression, actively involved in several cultural projects that aim to protect their language and identity (Laakso \& Sarhimaa 2016). In practical terms, the bureaucratic and financial opportunities for revitalization work have been strengthened by a new minority rights strategy established by the Swedish government in March 2009 and the new Act on National Minorities and National Minority Languages that took effect in 1 January 2010 (Lipott 2015, 13). However, despite the fact that Meänkieli is officially acknowledged as a minority language and used for other (cultural) purposes, the media supply in Meänkieli, for instance, is still relatively scarce; there is a local radio channel Meänraatio in Pajala which broadcasts daily for 3-4 hours, but visibility in publicservice TV is relatively rare and there are no daily newspapers published (Laakso \& Sarhimaa 2016).

\section{Research material}

The analysis in this research is implemented using a group discussion method. In minority studies, group discussions have been considered a unique methodological route through which oppressed minorities are offered a possibility to make their voices heard (Booth \& Booth 1996). Group discussions are a specific method through which the multiplicity of shared as well as contested narratives can be discovered (Price 2010). Discussions are analyzed by means of narrative inquiry, a method referring to a subset of qualitative research designs in which the act of 'hearing stories' is used as a sensitive tool to examine and describe human action (Polkinghorne 1995; Prokkola 2014). 
The studied material consists of 8 approximately 1-1.5 hour long tape-recorded group discussions conducted with 32 people of whom 17 were women and 15 men. Discussions were held in Haparanda, Övertorneå, Svanstein, Korpilombolo, Aapua and Pajala between September 2015 and February 2016. The participants were selected to represent people who are (inter-)actively working in several types of local associations and organizations operating around the Swedish side of the Torne Valley and are involved - some directly, some less directly - with the revitalization of Meänkieli; there were members of village associations and cultural associations, teachers from different levels of education, local radio reporters and musicians. Members for the groups were selected so that the participants were already familiar with each other, signifying a certain level of trust, and had a shared social bond related to the research topic.

The discussions were informal and spontaneous, and my purpose as a researcher was to take as passive a role as possible. For each discussion, a separate thematic framework was prepared, which contained questions relating to the specific activities of the interviewed group (music, radio broadcasting, teaching, religion, and so). In addition, there were some highly general questions that were directed to all interviewed groups concerning the local languages and identity. The key questions of this kind were: (1.) How do you see the work on Meänkieli language revitalization, and (2.) how does the issue of minority language come up or need to be acknowledged in your work? All discussions were conducted in Meänkieli, although there were natural alterations in language use depending on the backgrounds of different discussants. Some discussants conceived the language they used to be Finnish instead of Meänkieli, while for others the use of Swedish would have been more comfortable during the discussions. In fact, switching languages from Meänkieli/Finnish to Swedish and back again even during a single sentence, is typical for Meänkieli speakers and can be considered a specific characteristic of the language.

\section{Why saving Meänkieli is important?}

\section{For identity}

In the case of Meänkieli, 'our language', the name in itself implies how language can be an inseparable part of shared identity, which makes the revitalization work an end in itself. As has been argued across disciplinary boundaries, language is the very core of what we are, an essential part in everyday practices. It has been argued, that, on a general level, ethnic identities are constructed through language and everyday actions (Clayton 2009). As one male participant from Group 4 in a discussion humorously rephrased this, "it becomes a lousier meat, if you eat it in Swedish". In the discussions, Meänkieli speaking was often associated with coziness, with the feelings of 'being at home' (cf. Antonsich 2010). In one group, it was discussed how homely and cozy it felt when a church service was held in Meänkieli, although the event was also considered being highly unusual, exceptional and even somehow peculiar:

WOMAN 1: All events were told in Meänkieli. I must say that the more I have been involved with such things, the nicer has it been. It feels like it comes close to you when you hear it in your own dialect, when even the priest speaks in same manner as we do. And we sang those familiar hymns in Meänkieli.

(Group 7)

In a similar way as in (banal) everyday actions, the bond between language and identity is present visually, for example in local place name signages on a street. As reminders of local history, there are numerous places with Finnish names in the Swedish side of Torne Valley. Many of these can be traced back to the days when Finland was part of Sweden, but there are also several names from recent past, a particular type of nicknames being the most widespread, which are used in everyday interactions and which cannot be found on official maps. New names for places are constantly being 'invented' in real life situations, and in context of unique stories in which the identity and landscape fuses together: 
WOMAN 1 (20:30): In my opinion it is richness to know these names. It gives this love for home district. (...)

WOMAN 2: I feel too that it's important. That it gives like...

WOMAN 1: ...roots.

WOMAN 2: Yes, those roots are planted in those place names and places.

MAN 1: This fall we gave a new name to one bog. It did not have a name before. It is now called 'Backspegeljänkhä' (Rear-view mirror bog). We saw from our rear-mirror how an elk was crossing the road, so we started to call it 'Backspegeljänkhä'.

(Group 4)

Place names demonstrate how local history and the emotional bondage between language and identity is part of everyday activity. However, for Meänkieli speakers this emotional bondage is not only complex, but also politically charged in several ways. As Yuval-Davis (2006) has emphasized, identity needs to be studied on the levels of emotional attachments, social locations, and ethical and political values. The case of Meänkieli illustrates how 'we-feelings', as spatially embedded emotions, are not only about the feelings of belonging, but also about the feelings of being different (Richter 2015). One generation skipped learning the language because their parents were ashamed of their historical background. In trans-national families different languages are used for different purposes (Soler \& Zabrodskaja 2017), but in case of Finnish (or Meänkieli), avoiding speaking the language to your children was axiomatic, in-built norm: speaking Finnish was not an option. This is what the concept of hegemony means at its purest. Everything associated with Finnishness was regarded as lower in status. As a socio-culturally forced form of diglossia, home language was a signifier of social status and automatically hidden for the sake of appearing civilized.

What has been somewhat surprising is that, along the revitalization movement, the attitudes among youth have changed. In the discussions, it was often formulated that the children of the generation to whom Meänkieli was not been taught at home is now feeling that some part of who 'they are' has been stolen from them. In one group, this was discussed with a reference to Bengt Pohjanen's personal experiences:

MAN 1: Bengt Pohjanen, I think he had a good example. He says that when he in the 60 s went to Täräntö, to give some sort of a speech to school kids, he had asked how many of you can be speak Meänkieli, or Finnish. Everyone raised their hands. Around thirty in that room. And he did that same thing in the 80s, 1985 or 1986, and asked who can speak Meänkieli. There were two who raised their hands. That sort of a change during twenty years. Two out of thirty could speak.

MAN 2: In regrettable manner all those who speak and have roots here say that 'dear me, for why we did not teach our children'.

MAN 1: Yes, that's the way how it is and so say the children too, blame their parents.

MAN 3: Yes, I've heard hundreds and hundreds who say so.

(Group 3)

Avoiding speaking Meänkieli at home, for the sake of shame, has been later condemned by younger generation as an act of 'identity robbery'. In this manner, language revitalization work functions as an act to paying back, although it is worth asking to whom this compensation is actually directed. What this also implies and exemplifies is how identity narratives are rarely coherent and how, within one apparently coherent group, such as Meänkieli speakers, there can be competing narratives about the nature of identity. Among the identity studies conducted during the past two decades, more emphasis is put on the ambiguous nature of identity (Brubaker \& Cooper 2000). As mentioned, the connection of minority language and identity is geographically embedded issue in many ways (see further discussion, Gilmartin \& Migge 2015; Tomaney 2015; Ridanpää 2017). Although it is commonly shared opinion that Meänkieli is part of regional, Tornedalian identity, it is also constantly emphasized, how in different places the language is used in different ways. Similar diatopic variations can be found for example from Spain in where sociopolitical circumstances have diverted the phonetic and lexical diversity and spatiality of Galician dialects (Lorenzo 2012). In case of Meänkieli, diatopic variety sometimes leads to a (relatively absurd) debate about where the 'real' Meänkieli is spoken:

MAN 1: Then there is this question about where the real Meänkieli is spoken. Bengt Pohjanen said about twenty years ago, that real Meänkieli is spoken in Pajala municipality, in Täräntö. But all the people don't like that. 
MAN 2: But here (in Pajala) it has survived for quite a long time.

MAN 1: This is like a cradle of Meänkieli.

(Group 3)

WOMAN 1: It is so different in different villages, so what it is this real Meänkieli? There are so many versions of it.

WOMAN 2: I believe that, as you said (earlier), that where ever village you go, there is the real Meänkieli.

WOMAN 1: I know that upward - Muodoslombolo, Kitkajärvi - there they speak more like Finnish Finnish and here they speak more Swedish words, adding letter 'i' into the end.

(Group 5)

The concept of 'linguistic differentiation' refers to how languages are inherently discrete, bounded entities, embedded in the politics of a region and its observers (Irvine \& Gal 2000). There is a dominant conception that Meänkieli is a language spoken only in the Torne Valley, while the Torne Valley is usually defined as a river basin of Torne river. This is also in connection to a sociolinguistic concept of 'language authentication', the idea that some instances of a language are more authentic than others (McIntosh 2005, 1929). This causes conflicting opinions about who should be entitled as Meänkieli speakers, and who should not. As one woman in Group 8 exemplified this with her comment: "These people from ore mining fields, they think that they are from the Torne Valley". According to topographical definitions, the ore mining fields of northern Sweden are not a part of the Torne Valley and, despite the fact that the historical background of the people living there is connected to Finland, in terms of language politics, they are considered 'outsiders'. Some discussants considered this 'rivalry of belonging' a substantially annoying feature of Meänkieli language preservation:

WOMAN 1: What has bothered me a bit is that people are terribly restricted. Like if you belong to this group, you cannot belong to that group, because you are for example from Finland.

WOMAN 2: Exactly.

WOMAN 1: It shouldn't matter. The main thing is that we speak something. It's not relevant whether we speak more Finnish words or more Swedish words.

WOMAN 2: There are pedants everywhere.

(Group 7)

The geographical definition of the Torne Valley is inseparably attached to the definition of Meänkieli and how the connection between the language and identity is understood. One intriguing detail touching this issue can be found from the English version of Wikipedia, where the Swedish word 'Tornedalen' is translated, instead of the Torne Valley, as Meänmaa (in Eng. 'Our Country'), a concept invented by Bengt Pohjanen. By Meänmaa Pohjanen refers to a fluid region spreading across both sides of the border river, using language and culture as its determining attributes (Prokkola \& Ridanpää 2011). During the group discussions, it was frequently brought forth that Meänmaa, as a regional term, feels an artificial and unnecessary invention. From this perspective, the matter of introducing Torne Valley globally as Meänmaa, who ever has created this Wikipedia page, is a political act that promotes the recognition of Meänkieli as an independent language.

\section{For education}

It is axiomatic that the best medium for teaching a child is his mother tongue. Psychologically, it is the system of meaningful signs that in his mind works automatically for expression and understanding. Sociologically, it is a means of identification among the members of the community to which he belongs. Educationally, he learns more quickly through it than through an unfamiliar linguistic medium. (UNESCO 1953, 11)

As has been the case in several other language revitalization programs, the importance of importing the language into the school environment has been acknowledged in the Torne Valley as well. The right to use one's mother language, as one wishes to use it, is considered a part of general moral values of education. If we reflect the recent, positive development against the historical background of Swedification, certain intriguing nuances can be found. When discussing the societal history of Meänkieli, the marginalized position of language is (naturally) continuously emphasized by 
exemplifying how speaking Meänkieli in schools was forbidden in the early $20^{\text {th }}$ century. In several groups there were elder discussants who had personal experiences from the days when speaking Finnish in school was not formally forbidden anymore but still strongly disapproved. Against this background, the endeavors to bring Meänkieli into the school environment carry a significant symbolic value, although it is also likely that most of the younger generations are not highly aware of the local history of marginalization.

Among minority language studies, there has been abundant discussion about how various methods and techniques should be applied in education. Interestingly, in the interviews, the special role of 'having fun' as a pedagogical tool was recognized as important. In multi-disciplinary studies of humor, the educational value has often been underscored (Pollak \& Freda 1997; Van Wyk 2011). Similarly, teachers in Tornedalian schools maintain that 'having fun' should be utilized as a teaching method:

WOMAN 1: When you're working with Meänkieli it is important that you give a positive image of it, like it's fun and whatever you do with Meänkieli, should somehow be fun so that you get a feeling like: "wow, I wanna learn that too". A kind of interest and fascination rises, which helps the language survive and children are seriously willing to learn it and try to find those friends whom with it is possible to speak the language. So, for the sake of revitalization it is extremely important that it is made somehow interesting. And whatever you do with Meänkieli, it must be fun.

(Group 6)

Humor has played major role in the revitalization of Meänkieli (Ridanpää 2017). Especially after Niemi's (2010) Popularmusik från Vittula (Popular Music from Vittula), a humorous novel focusing on ironic features in the marginalization of Meänkieli, became a best-seller in Scandinavia, the general consciousness about the Meänkieli speakers roused all around Scandinavia (Ridanpää 2014). Interviewees also revealed that humor has played crucial role when Bengt Pohjanen's grammar education was broadcasted in local radio:

MAN 1: Like that language education what Bengt Pohjanen had then. It was this humor that got people interested.

MAN 2: Yes, it was made so that it was pure humor whole thing, that five minutes, and then that grammatical part five minutes.

(Group 3)

In addition to humor, it was also discussed how modern communication technologies can be used for the purpose of language work. While Romero (2016), among others, perceives modern communication technologies as a threat to language revitalization, in the group discussions, the case appeared to be that, via Facebook discussion forums, Meänkieli speakers all around Sweden have been able to sustain and rediscover their identity and shared feeling of belonging. Meänkieli is a regional language, but it is spoken in a marginal region, where the number of inhabitants is continuously decreasing. In order to keep Meänkieli speakers interested in their cultural heritage, the active maintenance of virtual communities, through modern information technologies, was considered highly important.

Education is a focal practical tool with which the minority languages can be kept alive, but educating a local language, as a part of Swedish school system, is also in connection to several other social and political processes. The revitalization of Meänkieli language and culture can be seen as part of a wider discussion concerning the rise of multiculturalism and polynationalism in Swedish society, as is also evidenced in the antagonistic responses from political groups against this development (Heith 2013, 86). Yet, the revitalization of Meänkieli is not only a part of a wider global linguistic movement and ethnic revival, but also connected to the recent global migration politics. In one group it was discussed whether this sociopolitical development is actually a hindrance to language work:

MAN 1: I have thought that those who come here, those new ones, they go immediately before Meänkieli teaching. Those who come from all sort of countries. It was said on radio that they should get their education in their own language here.

WOMAN 1: At the same I think it has been a little bit like a rescue for us, that legislation has changed. When they've had so much to ponder on them, at the same time it has turned better for us.

WOMAN 2: I think also that it's up to us whether they go before us or not. If we stick out for and want that Meänkieli, we can get it in same manner as they insist that people must have their own language.

(Group 4) 
Bringing Meänkieli to school is a complicated process in which the notions of 'them' and 'us' are constantly juxtaposed on several different ways. As we know from the history, the use of Meänkieli is usually reflected against the majority language, Swedish, but as has been illustrated here, globalization is making the situation increasingly complicated. Meänkieli is a local language, but on the Facebook forums, it attains features that reflect global features of language use. This raises a question, whether Meänkieli could actually be approached as 'a glocal' language, a viewpoint often applied to bilingual speakers (cf. Hornberger 2000; Lee \& Barton 2011).

\section{For sovereignty}

From a socially critical point of view, language revitalization represents action in which minority groups are attaining sovereignty and their self-determination in a wider sense. The right to use one's home language is an important part of everyday life, but there are also major symbolic meanings involved when minority languages become acknowledged and respected. This was especially topical when Meänkieli attained its official status as a minority language in 2000. Meänkieli is a language that is used in daily conversation, and in fact, there exists no tradition of reading or writing in Meänkieli. However, as discussed in one group, seeing Meänkieli printed has a major symbolic value:

WOMAN 1: Nobody demands anything in Meänkieli because Meänkieli speakers cannot necessarily read Meänkieli. All the Meänkieli speakers can read Swedish, so there hasn't been any need for it. Only so, as we have spoken, that in symbolic manner it is nice that we can see Meänkieli, like for example in municipality webpages there can be something in Meänkieli. So it's important that it's visible, but there has never been a situation in which someone insisted that things must be written also in Meänkieli.

(Group 6)

Although local inhabitants do not necessarily need or even want to see Meänkieli in printed form, it symbolizes the attainment of sovereignty, keeps the language existent in a concrete manner and removes it further away from the stigma of 'halflingualism'. As has been the case with several subalterned languages, no matter how the feelings of (regional) pride have started to flourish, the feelings of shame nevertheless remain embedded in the self-perception of the speakers of such languages. In the case of Meänkieli, the question of linguistic sovereignty is inherently connected to the bitterness directed at the denial of Finnish roots. Thus, the process of attaining sovereignty through language work involves this kind of resentment, and it is manifest in several ways in many of the group discussions. One of the male participants, for instance, told a story about how the election of a new county governor was notified in controversial manner in local news:

MAN 1: When this Kari Marklund became a county governor, as it had been decided by the government, it was then announced in local Swedish television, Norrbotten TV. They could not say his name as 'Kari', so it was changed as 'Karin Marklund'. That was the county governor in Norrbotten.

WOMAN 1: And this was in the 90s.

MAN 1: It was in the 90s. Karin Marklund, a man with such a name had become a county governor. So yes, it has been bloody effective politics, oppressing people and at the same time Sweden represented the global self-esteem in many issues.

(Group 8)

As Karin is a Swedish female name, this (probably accidently announced) wrong name is turned into a bitter-sweet humorous story in which the internal colonialism imposed by Swedish society becomes criticized. Similarly, it illustrates how ethnic minorities are capable of turning their marginal position into a source of pride and even of laughing at themselves (Ridanpää 2017, 67-68). In that same group discussion, the societal status of Meänkieli was also defended by re-narrating the history of Finnish language:

MAN 1: It has been acknowledged that, ever since the Torne Valley has been populated, say back to the $10^{\text {th }}-11^{\text {th }}$ century, the language spoken here was Meänkieli. (...) Finnish, the national language of Finland, it was not before $16^{\text {th }}$ century when Mikael Agricola started mucking around with it. It was not until the middle of $19^{\text {th }}$ century when Finnish became a public, national language. It is so that if you take a more in-depth look, the national language of Finland is a dialect of Meänkieli, if 
you may, not other way around.

MAN 2: Yes, invented language.

(Group 8)

Whether the discussant in the example above is being serious or merely speaking in jest is irrelevant here. According to discussants, Meänkieli contains something pure and original that other, officially acknowledged languages do not have. The feeling of being othered is constantly embedded when discussing the societal position of Meänkieli and, interestingly, this bitterness is directed both at the history of Swedification as well as at the history of Finnish society.

\section{On the other hand...}

It has been highlighted in this article that the revitalization of Meänkieli has been in a key role in the revitalization of the regional identity. Similarly, Meänkieli has been in a key role when local people have mobilized themselves to work for the benefit of local culture on a more general level. However, some discussants, particularly those who are not directly working in language revitalization programs, feel that revitalization work has perhaps gone too far, that there is simply 'too much' Meänkieli everywhere:

WOMAN 1: Some say that it's too much, like in all occasions it is Meänkieli, Meänkieli. (Group 5)

WOMAN 1: I am not sure whether I'm a right person to say, since I'm a little bit like a Finn and I speak Finnish and try to teach Finnish. Sometimes it feels like it has turned into a kind of myth, that municipalities must have Meänkieli and it must be used.

(...)

WOMAN 2: It somehow feels like the language shouldn't be (used) against one's own will. If there is no use for language, it will die anyway.

(Group 2)

Minority identity and language as one element of it, are not stable and coherent discourses, but there are various, sometimes conflicting narratives of who 'we' are and where 'we' come from. According to one interviewee, Meänkieli speaking has turned, on regional level, into a hegemonic discourse, which is not necessarily only positive:

MAN 1: Linguistically, it seems like that Meänkieli, as a name, has gained a kind of monopoly here in Swedish side, on the western side of the border. Nobody speaks about Finnish. (...)

As a name, Meänkieli has then overtook (...) that what language is spoken here, at this side of the border. Haparanda is actually that island, in where we still say, that we speak Finnish, but in other municipalities up north, the title is Meänkieli. (...)

It is something that enables to deny own roots, when being Meänkieli speakers. On no account being Finnish. Not even from our roots. It is same thing there in Finnmark, Norway. It is only talked about Kven people, (...) not anymore about Finnmark people or the Finns. They are Kvens nowadays. No matter whether they wanted it or not.

(Group 1)

Although the revitalization of Meänkieli has been recognized as a matter of regional pride, a cornerstone of shared identity, here Meänkieli is conceived rather as a symbolic signpost with which, not only the history of otherness, but also the historical origins of local identity, the Finnish language and Finnish roots, can be denied and forgotten. In case of Meänkieli, the language revitalization work obviously serves to benefit identity work, but as an interviewee conceives here, in a slightly contradicting manner, with the cost of the decreasing appreciation of Finnish identity and roots. Calling 'Tornedalian Finska' as Meänkieli has been a strategic move and it is understandable that for some, even those being actively involved with revitalization work, the artificiality may feel irritating:

WOMAN 1: I have always said that I speak Finnish, but it was before that Meänkieli was invented. (Group 2)

MAN 1: What I find really sad is this denial of Finnishness so that even names are changed. Many men here have taken their wives' surname after cross-marrying, taken wife's surname, because it 
is Swedish. Then changed the first name a little bit, like sounding more Swedish. Then many invented own dialect and denies then the Finnish background of it. It's like I think that one must know where one comes from, where the roots are, but these deny it completely, that Finnishness. I don't understand what it is this shame that it has caused to them.

(Group 1)

As has been mentioned in this article, Bengt Pohjanen has been a key person in the mobilization of language revitalization and his dedication to work for this goal has been widely appreciated. Establishing the grammar for Meänkieli is perceived as a crucial symbolic signpost for language revitalization. Yet, although Pohjanen's work - particularly on grammar - legitimizes the position of Meänkieli as an independent minority language, it is also perceived that standardizing everyday language may actually hinder its survival:

MAN 1: When that grammar came, when they started working with that book, (...), I have sometimes pondered it like by that means it is made more difficult than it actually is. When you start phrasing like, "this must be in that form, this is correct, this is wrong", then you prevent the language from developing, I think.

WOMAN 1: Yes, then the interest stops.

(...)

MAN 1: I believe that if language must survive, it must be...

MAN 2: Free

MAN 1: Yes, free. And it isn't that serious if something is said wrong.

(Group 6)

As seen, although all the discussants share the opinion that the survival of Meänkieli is important in general, some discussants believe that certain aspects of language revitalization may actually work against their own purpose. It is presumable that the speaker in the previous example does not think that 'let it be' is the best method to save the language, but what it illustrates is that there are varying opinions about how seriously the language work should be put into action. Discussants in the previous example imply that the existence of Meänkieli is dependent on that it is used as a colloquial language in daily conversation and, therefore, establishing a grammar for it hinders the natural way of using it. This demonstrates how diverging and also confronting rationales for language revitalization work there exist.

\section{Discussion}

The simple conclusion from the discussion is that, on a local level, the variety of rationales for language revitalization is vast. As Costa and Gasquet-Cyrus $(2013,223)$ argue, "no revitalization movement can ever be homogenous", and that "such movements are born of the creation of charter myths and are based subsequently on interpretations that serve various (and often conflicting) interests". Among the people actively working with or for the survival of Meänkieli, there exist varying opinions about why saving language is important. In addition, the opinions about how to operationalize the revitalization process are diverse. Ultimately, the most important finding is that language revitalizing is not a path of action that was carried without questioning its logics. The language is recognized as a part of people's identity, so although all the discussants were somehow involved with language revitalization work, for some the negative connotations attached to Meänkieli were too intimate. In addition, as has been highlighted at the end, some discussants suggested that language revitalization work has become too dominant a mode of cultural activity. Language revitalization has been a process of renarrating the local history (Ridanpää 2014), but for some discussants it represents, rather surprisingly, a new way to re-hide the shameful past.

In the Torne Valley, language revitalization work has been carried out along with other cultural projects funded by the European Union, and similarly, the received funding has mobilized new cultural projects. In fact, there exists also a viewpoint according to which the urge for Meänkieli language revitalization functions solely for the benefit of achieving more funding from the European Union for other cultural activities and projects. Against this background, it was an interesting and relatively surprising finding that the protection of Meänkieli was not rationalized by the relevance of cultural 
diversity. Instead, the language revitalization efforts can be approached as a form of meta-culture. The notion of meta-culture refers to "cultural forms or practices that comment on other cultural forms or practices, and in so doing, impact their circulation" and "metapragmatic discourses explicitly attempting to change language structure, function, and social usage or undo previous changes" (McEwan-Fujita 2011, 48). For cultural activists and people who are involved with language revitalization via some cultural activity, the intrinsic value of cultural diversity is axiomatic and not explicitly mentioned or even implicitly referred to.

It has been criticized that, when discussing about saving the language through recording and documentation, many language experts use metaphorical framing such as 'death', 'endangerment' and 'extinction', which may have a negative impact on those community members who are actively revitalizing and reclaiming languages (Perley 2012). Arguments such as "more hard we work, more endangered it is" or "this language is dying anyway" were voiced in the group discussions. This illustrates clearly how trust in a bright future is often wavering and the metaphoric frames of 'death', 'endangerment' and 'extinction' are actively in use in conversations among the language activists as well - or should we say, especially among them. It seems that more signs of threat need to appear in order to make people realize the gravity of the current situation concerning the decline of minority languages, no matter for what rationale saving endangered languages is conceived important.

\section{Acknowledgements}

Research was financially supported by Kone Foundation.

\section{References}

Ahola, L. (2006) Asenteellista menoa - tornionlaaksolaiset nuoret ja vähemmistökieli. In Haurinen, O. \& Sulkala, H. (eds.) Tutkielmia vähemmistökielistä Jäämereltä Liivinrantaan: Vähemmistökielten tutkimus- ja koulutusverkoston raportti V, 15-29. Oulu University Press, Oulu.

Albury, N. J. (2017) Mother tongues and languaging in Malaysia: critical linguistics under critical examination. Language in Society 46(4) 567-589. https://doi.org/10.1017/S0047404517000239

Antonsich, M. (2010) Searching for belonging - an analytical framework. Geography Compass 4(6) 644-659. https://doi.org/10.1111/j.1749-8198.2009.00317.x

Baloy, N. (2011) "We can't feel our language": making places in the city for aboriginal language revitalization. The American Indian Quarterly 35(4) 515-548. https://doi.org/10.5250/ amerindiquar.35.4.0515

Booth, T. \& Booth, W. (1996) Sounds of silence: narrative research with inarticulate subjects. Disability \& Society 11(1) 55-70. https://doi.org/10.1080/09687599650023326

Brubaker, R. \& Cooper, F. (2000) Beyond "identity". Theory and Society 29(1) 1-47. https://doi. org/10.1023/A:1007068714468

Clayton, J. (2009) Thinking spatially: towards an everyday understanding of inter-ethnic relations. Social and Cultural Geography 10(4) 481-498. https://doi.org/10.1080/14649360902853288

Costa, J. \& Gasquet-Cyrus, M. (2013) What is language revitalization really about? Competing language revitalization movements in Provence. In Jones, M. J. \& Ogilvie, S. (eds.) Keeping Languages Alive: Documentation, Pedagogy and Revitalization, 212-224. Cambridge University Press, Cambridge. https://doi.org/10.1017/CBO9781139245890.020

Davis, J. L. (2016) Language affiliation and ethnolinguistic identity in Chickasaw language revitalization. Language \& Communication 47 100-111. https://doi.org/10.1016/j.langcom.2015.04.005

Dorian, N. C. (1994) Purism vs. compromise in language revitalization and language revival. Language in Society 23(4) 479-494. https://doi.org/10.1017/S0047404500018169

Edwards, J. (2010) Minority Languages and Group Identity. John Benjamins B.V., Amsterdam. https:// doi.org/10.1075/impact. 27

Elenius, L. (2002) A place in the memory of nation. Minority policy towards the Finnish speakers in Sweden and Norway. Acta Borealia 19 103-123. https://doi.org/10.1080/080038302321117542

Fishman, J. A. (1991) Reversing Language Shift: Theoretical and Empirical Foundations of Assistance to Threatened Languages. Multilingual matters, Clevendon. 
Friedman, D. A. (2011) Language socialization and language revitalization. In Duranti, A., Ochs, E. \& Schieffelin, B. B. (eds.) The Handbook of Language Socialization, 631-647. Wiley-Blackwell, West Sussex. https://doi.org/10.1002/9781444342901.ch27

Gibson, C. (1998) "We sing our home, we dance our land": indigenous self-determination and contemporary geopolitics in Australian popular music. Environment and Planning D: Society and Space 16 163-184. https://doi.org/10.1068/d160163

Gilmartin, M. \& Migge, B. (2015) Home stories: immigrant narratives of place and identity in contemporary Ireland. Journal of Cultural Geography 32(1) 83-101. https://doi.org/10.1080/08873 631.2014 .1000576

Grenoble, L. A. \& Whaley, L. J. (2006) Saving Languages: An Introduction to Language Revitalization. Cambridge University Press, Cambridge.

Hansegård, N. (1990) Den norrbottensfinska språkfrågan: en återblick på halvspråkighetsdebatten. Centre for Multiethnic Research, Uppsala.

Harrison, K. D. (2008) When Languages Die: The Extinction of the World's Languages and the Erosion of Human Knowledge. Oxford University Press, Oxford.

Heith, A. (2013) Challenging and negotiating national borders: Sámi and Tornedalian alternative literary history. In Viljoen, H. (ed.) Crossing Borders, Dissolving Boundaries, 75-91. Rodopi, Amsterdam.

Hermes, M. (2012) Indigenous language revitalization and documentation in the United States: collaboration despite colonialism. Language and Linguistics Compass 6(3) 131-142. https://doi. org/10.1002/Inc3.327

Hermes, M. \& King, K. (2013) Ojibwe language revitalization, multimedia technology, and family language learning. Language Learning \& Technology 17(1) 125-144. < http://hdl.handle. net/10125/24513>

Hinton, L. (2001) Language revitalization: an overview. In Hinton, L. \& Hale, K. (eds.) The Green Book of Language Revitalization in Practice, 3-18. Academic Press, San Diego. https://doi. org/10.1163/9789004261723002

Hinton, L. (2011) Language revitalization and language pedagogy: new teaching and learning strategies. Language and Education 25(4) 307-318. https://doi.org/10.1080/09500782.2011.577220

Hornberger, N. H. (2000) Bilingual education policy and practice in the Andes: ideological paradox and intercultural possibility. Anthropology \& Education Quarterly 31(2) 173-201. https://doi. org/10.1525/aeq.2000.31.2.173

Hornberger, N. H. (2006) Voice and biliteracy in indigenous language revitalization: contentious educational practices in Quechua, Guarani, and Māori contexts. Journal of Language, Identity, and Education 5(4) 277-292. https://doi.org/10.1207/s15327701jlie0504_2

Huss, L. M. (1999) Reversing Language Shift in the Far North: Linguistic Revitalization in Northern Scandinavia and Finland. Acta Universitatis Upsaliensis, Uppsala.

Irvine, J. T. \& Gal, S. (2000) Language ideology and linguistic differentiation. In Kroskrity, P. V. (ed.) Regimes of Language, 35-83. School of American Research Press, Santa Fe.

Júlíusdóttir, M. (2007) Culture, cultural economy and gender in processes of place reinvention. In Nyseth, T. \& Granås, B. (eds.) Place Reinvention in the North-Dynamics and Governance Perspectives, 39-53. Nordregio, Stockholm.

Karlsson, B. (ed.) (2004) Bengt Pohjanen - Meän vanhiin. Barents Publisher, Överkalix.

King, J. (2001) Te Kohanga Reo: Maori language revitalization. In Hinton, L. \& Hale, K. (eds.) The Green Book of Language Revitalization in Practice, 119-128. Academic Press, San Diego.

King, K. A. (2001) Language Revitalization Processes and Prospects: Quichua in the Ecuadorian Andes. Multilingual Matters, Clevedon. https://doi.org/10.21832/9781853597077

King, K. A. (ed.) (2008) Sustaining Linguistic Diversity: Endangered and Minority Languages and Language Varieties. Georgetown University Press, Georgetown.

Laakso, J. \& Sarhimaa, A. (2016) Towards Openly Multilingual Policies and Practices: Assessing Minority Language Maintenance Across Europe. Multilingual Matters, Bristol.

Lane, P. (2011) The birth of the Kven language in Norway: emancipation through state recognition. International Journal of the Sociology of Language 2011(209) 57-74. https://doi.org/10.1515/ ijsl.2011.021

Lee, C. K. M. \& Barton, D. (2011) Constructing glocal identities through multilingual writing practices on Flickr.com ${ }^{\circledR}$. International Multilingual Research Journal 5(1) 39-59. https://doi.org/10.1080/193 13152.2011.541331 
Lindgren, A. R. (2000) Language emancipation: the Finnish case. In Phillipson, R. (ed.) Rights to Language: Equity, Power and Education, 40-45. Laurence Erlbaum Associates, Mahwah.

Lipott, S. (2015) The Tornedalian minority in Sweden. From assimilation to recognition: a 'forgotten' ethnic and linguistic minority, 1870-2000. Immigrants \& Minorities 33(1) 1-22. https://doi.org/10.1 $\underline{080 / 02619288.2014 .896539}$

Lorenzo, D. R. (2012) The diatopic development of aspects of twentieth-century Galician. A contrastive analysis of linguistic geography data. Dialectologia: Revista Electronica 2012 143-156.

Marten, H. F. (2012) 'Latgalian is not a language': linguistic landscapes in Eastern Latvia and how they reflect centralist attitudes. In Gorter, D., Marten, H. F. \& Van Mensel, L. (eds.) Minority Languages in the Linguistic Landscape, 19-35. Palgrave Macmillan, UK.

May, S. (2012) Language and Minority Rights: Ethnicity, Nationalism and the Politics of Language. Routledge, New York.

McCarty, T. L., Nicholas, S. E. \& Wyman, L. T. (2015) 50(0) years out and counting: Native American language education and the four Rs. International Multilingual Research Journal 9(4) 227-252. https://doi.org/10.1080/19313152.2015.1091267

McCarty, T. L., Romero-Little, M. E., Warhol, L. \& Zepeda, C. (2009) Indigenous youth as language policy makers. Journal of Language, Identity, and Education 8(5) 291-306. https://doi. org/10.1080/15348450903305098

McEwan-Fujita, E. (2011) Language revitalization discourses as metaculture: Gaelic in Scotland from the 18th to 20th centuries. Language \& Communication 31(1) 48-62. https://doi.org/10.1016/j. langcom.2010.12.001

McIntosh, J. (2005) Language essentialism and social hierarchies among Giriama and Swahili. Journal of Pragmatics 37(12) 1919-1944. https://doi.org/10.1016/j.pragma.2005.01.010

Meek, B. A. (2010) We Are Our Language: An Ethnography of Language Revitalization in a Northern Athabaskan Community. University of Arizona Press, Tucson.

Napurí, A. (2016) Revitalization of the Bora language. In Pericles, P. (ed.) Springer International Handbooks of Education: Handbook of Research and Practice in Heritage Language Education, 1-13. Themistoklis Aravossitas Springer, Trifonas. https://doi.org/10.1007/978-3-319-38893-9_24-1

Niemi, M. (2000) Popularmusik från Vittula. Norstedt, Stockholm.

O'Rourke, B. \& Pujolar, J. (2013) From native speakers to "new speakers" - problematizing nativeness in language revitalization contexts. Histoire Épistémologie Langage 35(2) 47-67. https://www. persee.fr/doc/hel 0750-8069 2013 num 3523457

Olthuis, M., Kivelä, S. \& Skutnabb-Kangas, T. (2013) Revitalising Indigenous Languages: How to Recreate a Lost Generation. Multilingual matters, Bristol. https://doi.org/10.21832/9781847698896

Pasanen, A. (2015) Kuávsui já peeivičuovâ.'Sarastus ja päivänvalo': Inarinsaamen kielen revitalisaatio. Uralica Helsingiensia, Helsinki.

Peltonen, M. (2000) Between landscape and language: The Finnish national self-image in transition. Scandinavian Journal of History 25(4) 265-280. https://doi.org/10.1080/034687500750046924

Perley, B. C. (2012) Zombie linguistics: experts, endangered languages and the curse of undead voices. Anthropological Forum: A Journal of Social Anthropology and Comparative Sociology 22(2) 133-149. https://doi.org/10.1080/00664677.2012.694170

Piasecki, K. (2014) The birth of new ethnoses: examples from Northern Europe. Our Europe. Ethnography - Ethnology - Anthropology of Culture 3/2014 7-20. <http://yadda.icm.edu.pl/yaddal element/bwmeta1.element.desklight-a1a9b84d-5474-4e41-84b5-02870ec54088> 26.11.2018.

Pietikäinen, S., Huss, L., Laihiala-Kankainen, S., Aikio-Puoskari, U. \& Lane, P. (2010) Regulating multilingualism in the North Calotte: the case of Kven, Meänkieli and Sámi languages. Acta Borealia 27(1) 1-23. https://doi.org/10.1080/08003831.2010.486923

Polkinghorne, D. E. (1995) Narrative configuration in qualitative analysis. International Journal of Qualitative Studies in Education 8(1) 5-23. https://doi.org/10.1080/0951839950080103

Pollak, J. P. \& Freda, P. D. (1997) Humor, learning, and socialization in middle level classrooms. The Clearing House: A Journal of Educational Strategies, Issues and Ideas 70(4) 176-178. https://doi.org/1 0.1080/00098655.1997.10544190

Price, P. L. (2010) Cultural geography and the stories we tell ourselves. Cultural Geographies 17(2) 203-210. https://doi.org/10.1177/1474474010363851

Prokkola, E-K. (2014) Using narrativity as a methodological tool. ACME: An International E-Journal for Critical Geographies 13(3) 442-449. <https://www.acme-journal.org/index.php/acme/articlel view/1018> 
Prokkola, E-K. \& Ridanpää, J. (2011) Following the plot of Bengt Pohjanen's Meänmaa: narrativization as a process of creating regional identity. Social \& Cultural Geography 12(7) 775-791. https://doi.or $\mathrm{g} / 10.1080 / 14649365.2011 .615666$

Rata, E. (2007) Maori language survival and New Zealand education. In Schuster, K. \& Witkosky, D. (eds.) Language of the Land. Policy, Politics, Identity, 79-98. Information Age, Charlotte (N.C.).

Rice, K. (2009) Must there be two solitudes? Language activists and linguists working together. In Reyhner, J. \& Lockard, L. (eds.) Indigenous Language Revitalization: Encouragement, Courage and Lessons Learned, 37-59. Northern Arizona University, Flagstaff, AZ.

Richter, M. (2015) Can you feel the difference? Emotions as an analytical lens. Geographica Helvetica 70(2) 141-148. https://doi.org/10.5194/gh-70-141-2015

Ridanpää, J. (2014) Politics of literary humour and contested narrative identity (of a region with no identity). Cultural Geographies 21(4) 711-726. https://doi.org/10.1177/1474474014525054

Ridanpää, J. (2016) Singing acts from the deep North: critical perspectives on northern exotics, contemporary ethnic music and language preservation in Sámi communities. Journal for Cultural Research 20(1) 17-30. https://doi.org/10.1080/14797585.2015.1134057

Ridanpää, J. (2017) Narrativizing (and laughing) spatial identities together in Meänkieli-speaking minorities. Geoforum 83 60-70. https://doi.org/10.1016/j.geoforum.2017.05.003

Ridanpää, J. \& Pasanen, A. (2009) From the Bronx to the wilderness: Inari-Sami rap, language revitalisation and contested ethnic stereotypes. Studies in Ethnicity and Nationalism 9(2) 213-230. https://doi.org/10.1111/j.1754-9469.2009.01051.x

Romero, S. (2016) Bill Gates speaks K'ichee'! The corporatization of linguistic revitalization in Guatemala.Language \& Communication 47154-166. https://doi.org/10.1016/j.langcom.2015.08.001

Sallabank, J. (2013) Attitudes to Endangered Languages: Identities and Policies. Cambridge University Press, New York. https://doi.org/10.1017/CBO9781139344166

Skutnabb-Kangas, T. (2002) Language policies and education: the role of education in destroying or supporting the world's linguistic diversity. In World Congress on Language Policies, Barcelona.

Soler, J. \& Zabrodskaja, A. (2017) New spaces of new speaker profiles: exploring language ideologies in transnational multilingual families. Language in Society 46(4) 547-566. https://doi.org/10.1017/ S0047404517000367

Spolsky, B. (1995) Conditions for language revitalization: a comparison of the cases of Hebrew and Maori.Current/ssuesinLanguage\&Society2(3)177-201.https://doi.org/10.1080/13520529509615444

Sullivan, T. (2012) 'I want to be all I can Irish': the role of performance and performativity in the construction of ethnicity. Social \& Cultural Geography 13(5) 429-443. https://doi.org/10.1080/146 49365.2012.698746

Sumida Huaman, E. (2014) "You're trying hard, but it's still going to die": indigenous youth and language tensions in Peru and the United States. Anthropology \& Education Quarterly 45(1) 71-86. https://doi.org/10.1111/aeq.12048

Tomaney, J. (2015) Region and place II: belonging. Progress in Human Geography 39(4) 507-516. https:// doi.org/10.1177/0309132514539210

Tsunoda, T. (2005) Language Endangerment and Language Revitalization: An Introduction. De Gruyter Mouton, Berlin.

UNESCO (1953) The Use of Vernacular Languages in Education. UNESCO, Paris.

Vaattovaara, J. (2009) Meän tapa puhua: Tornionlaakso pellolaisnuorten subjektiivisena paikkana ja murrealueena. Suomalaisen Kirjallisuuden Seura, Helsinki.

Valentine, G. \& Skelton, T. (2007) The right to be heard: citizenship and language. Political Geography 26(2) 121-140. https://doi.org/10.1016/j.polgeo.2006.09.003

Van Wyk, M. M. (2011) The use of cartoons as a teaching tool to enhance student learning in economics education. Journal of Social Science 26(2) 117-130. https://doi.org/10.1080/09718923.2 011.11892888

Warschauer, M., Donaghy, K. \& Kuamoÿo, H. (1997) Leokī: a powerful voice of Hawaiian language revitalization. Computer Assisted Language Learning 10(4) 349-362. https://doi. org/10.1080/0958822970100405

Wilson, A. C. (2004) Reclaiming our humanity: decolonizing and recovery of Indigenous knowledge. In Mihesuah, D. A. \& Wilson, A. C. (eds.) Indigenizing the Academy: Transforming Scholarship and Empowering Communities, 69-87. University of Nebraska Press, Lincoln.

Winsa, B. (2007) Social capital of indigenous and autochthonous ethnicities. In Dana, L. P. \& Anderson, R. B. (eds.) International Handbook of Research of International Entrepreneurship, 257-286. Edward Elgar Publishing, Chelterham. https://doi.org/10.4337/9781781952641.00031 
Woolard, K. A. (2003) We don't speak Catalan because we are marginalized. Ethnic and class connotations of language in Barcelona. In Blot, R. K. (ed.) Language and Social Identity, 85-103. Praeger, Westport, CP.

Yuval-Davis, N. (2006) Belonging and the politics of belonging. Patterns of Prejudice 40(3) 197-214. https://doi.org/10.1080/00313220600769331 